\title{
Implementation of Problem-Based Learning (PBL) Approach in Chemistry Instructional with Context of Tofu Liquid Waste Treatment
}

\author{
Momo Rosbiono Kartamiharja, Wahyu Sopandi and Dini Anggraeni \\ Universitas Pendidikan Indonesia, Indonesia \\ https://orcid.org/0000-0001-6345-7399 \\ https:/ / orcid.org/0000-0002-1501-4064 \\ https://orcid.org/0000-0002-8164-8807
}

\begin{abstract}
This research aims to determine the effectiveness of the Problem-Based Learning (PBL) approach implementation in chemistry instructional with the context of tofu wastewater treatment. This research used mixed methods with concurrent embedded research strategies and pre-experiment one-group pretest-posttest design. The subject of this study consisted of one chemistry teacher as a presenter, three teachers as observers, and 34 Class XI students in a High School in Bandung Indonesia. The instruments were lesson plan evaluation format, student worksheet evaluation format, students' skill and attitude observation format with a content-validated rubric, and test items with the reliability coefficient of Kuder Richardson of 0.73 . The research findings indicated that the PBL instructional planning strategy was classified as very good in terms of formulating learning outcomes, learning material compilation, and evaluation tools. The compilation of learning media and instructional stages were in good categories. Students' performance displayed in all stages of PBL from problem identification to problem-solving was categorized as good. The results also showed that students' learning outcomes in understanding the concepts of tofu wastewater treatment increased from 50 (the average pre-test score) to 85 (post-test). The increase in learning outcomes was categorized medium with the N-gain score of 0.67. Based on these findings and results, it can be concluded that instructional with the PBL approach can improve students' learning processes and outcomes in chemistry learning.
\end{abstract}

Keywords: instruction; PBL; planning strategy; instruction implementation; tofu liquid waste treatment

\section{Introduction}

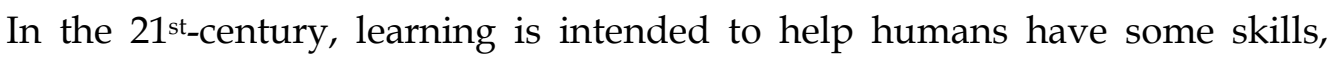
namely 1) thinking skills, 2) work skills, 3) skills in the use of technology, 
information and developing literacy, 4) social responsibility and competency (Griffin \& Care, 2015). Twenty-first-century skills can be obtained through education. Education is a conscious and planned effort so that students actively develop their potential (Depdiknas, 2003; Stivaktakis, 2017).

The sustainability of Indonesian education is accommodated by the curriculum. The curriculum used is the 2013 curriculum with the principle of learning in which students begin to find out and teachers are not the only source of learning, meanwhile strengthening the use of scientific approaches and communication information technology (Depdikbud, No. 22, 2016). Therefore, an innovative learning approach that is formed through the flow of constructivism is needed (Overton \& Randles, 2013; Schell \& Kaufman, 2015). One learning approach that is following the learning principle above is the Problem-Based Learning approach (Direktorat Pembinaan Sekolah Menengah Atas, 2017). Problem-Based Learning (PBL) was introduced at Case W. University School of Medicine in the United States around the 1950s (Üce \& Ateş, 2016). PBL has student-centered learning characteristics, where students carry out learning independently, identify the problems they will be working on and determine sources of information likes books, journals, internet, etc. (Savery, 2006). PBL is also done based on scenarios and adjusted to realistic or real problems which then makes students proficient in problem-solving and group work (Gurses et al., 2015; Wijayanti \& Wulandari, 2016). The PBL approach has the characteristics of problem submission, an interdisciplinary focus, official investigations, product production, as well as publication and collaboration (Arends, 2012).

However, the use of PBL has not been optimized. The purpose of the PBL approach still lacks in learning; although it is implemented, PBL syntaxes are still not appropriate (Zulfaidhah, Palenewen \& Hardoko, 2018). Tan Type, one type of PBL, has 5 steps, namely, step (1) meeting the problem, step (2) analyzing the problem and learning issues, step (3) discovery and reporting, step (4) presenting solution and reflection, and step (5) summarizing, integrating, and evaluating (Tan, 2003). The implementation of the PBL approach provides positive results for students, including research results from Aidoo, Pangaribuan and Pratiwi. In the research conducted by Aidoo, the experimental group had a higher chemistry achievement (Aidoo, 2016) and Pangaribuan (2016) found that students' mastery of concepts increased by $20.4 \%$. In Pratiwi's research, PBL was able to increase the percentage of students which reached the minimum score on redox material by $81.25 \%$ (Pratiwi, 2014). Viewed from the context of improving the quality of education, PBL can be used to improve learning systems and improve the students' ability to solve problems (Sanjaya, 2006). Thus, learning with the PBL approach was chosen by researchers because it was able to improve students' performance and understanding, help students understand problems in daily life, develop students' knowledge, help them to be responsible for their learning (Wulandari, 2014).

To implement PBL, instructional planning is needed. Instructional planning is a guide prepared by the teacher in the implementation of the learning process 
(Sanjaya, 2015). Instructional implementation plans refer to the content standards and preparation of instructional strategies, including the development of lesson plans and preparation of media, learning resources, evaluation tools, and learning scenarios (Depdikbud, No. 23, 2016). In the chemistry syllabus, class XI high school students are required to master the concept of the colloidal system material which is quite tricky for students. For example, there are students' misconceptions about the colloidal system material, including distinguishing colloids, the concept of colloid making, the nature of colloids, and colloids in life. Besides, students experience misconceptions in the sub-concept of coagulation and confused with dialysis and adsorbs. Thus, colloidal system material is quite difficult for students to understand, one of which is in the coagulation sub material ( Dj, Fitri \& Dewata, 2015).

In this research, the chosen context is the handling of tofu liquid waste because it contains colloidal particles that can pollute the environment, such as increasing turbidity. These problems can be solved by coagulation, which is to coagulate colloidal particles into more extensive and deposited particles to reduce turbidity (Ramadhani \& Moesria, 2013; Septiana, 2014; Wulandari, 2014; Sudarmo, 2017; Puspasari, 2017). These problems can be used as a context in PBL learning and know-how they affect the mastery of students' concepts in the concept of colloidal systems, the nature of colloids (coagulation), and the context of tofu wastewater treatment by condensation.

Based on the explanation above, this study aims to:

1. Know the effectiveness of the planning strategy or the design of the Problem-Based Learning approach in instructional chemistry in the context of tofu wastewater treatment.

2. Know students' performance in the process of implementing the ProblemBased Learning approach in learning with the context of tofu wastewater treatment.

3. Identify students' learning outcomes after carrying out chemistry instruction using the Problem-Based Learning approach with the context of tofu wastewater treatment.

\section{Methods}

In this study, the method used is Mixed Methods, a research method that combines quantitative methods with qualitative methods (Creswell, 2009). The research strategy is Concurrent Embedded with the One Group Pretest-Posttest research design, where one selected group is measured and observed before and after treatment (Ary, 2010).

This research was conducted at a high school in Bandung, Indonesia. The selected research subjects were one chemistry teacher as a presenter, three chemistry teachers as the observers, and 34 students of Class XI Mathematics and Science (Chemistry). Participants are students who have learned the concept of the heterogeneous and homogeneous mixture, the concept of 
solution, and the concept of the electrolyte solution. A description of the flow in this study was explained as follows:

\section{Preparation Stage}

a. Identifying chemistry problems and chemistry learning which are quite popular and can be solved through problem-based learning (PBL).

b. Analyzing Core Competency and Basic Competency according to Curriculum 2013.

c. Conduct a PBL literature study.

d. Analyzing concepts, problems, and solutions to solve issues and materials.

e. Making instructional tools (lesson plans and appendices).

f. Making an evaluation instrument that includes teacher performance rubric, student worksheet evaluation sheet, attitude and performance observation sheet, test items, and a validation sheet.

g. Validating learning tools and evaluation instruments, then revising if there are improvements.

2. Implementation Stage

a. Pretest, to find out the initial abilities of students.

b. PBL treatment.

c. Posttest, to determine the learning outcomes of instructional using PBL.

3. Final Stage

a. Manging data of the pretest and posttest evaluation results in the form of a written test.

b. Analyzing the results of research and discussion.

c. Make conclusions.

The four instruments used in this research were lesson plan evaluation format, student worksheet evaluation format, students' skill and attitude observation format, and test items. The first three instruments were content validated by chemistry education experts and the reliability test KR-20 (Kuder-Richardson20) was carried out on the fourth instrument with a value of 0.73 (highreliability category).

The lesson plan evaluation format was used to reveal the ability of chemistry teachers in planning to learn using the PBL approach in the context of tofu liquid waste management in high schools. The student worksheet evaluation format was used to reveal the ability of high school students to carry out the problem-solving stage for tofu liquid waste handling based on the PBL instructional approach. Student attitude and performance observation sheets were used to observe the attitudes and laboratory work skills of high school students during PBL instruction in tofu liquid waste management. Test items were used to reveal the basic concepts of colloid chemistry and the application of high school students before (pre-test) and after (post-test) following PBL learning in the treatment of tofu liquid waste.

The evaluation score for chemistry teachers and students during PBL instruction in the management of tofu wastewater were categorized based on the rules developed by Aqib (2009). The categories are divided into a very good 
category which was given for scores ranging from 86 to 100, good category for scores ranging from 71 to 85 , average category for scores ranging from 56 to 70 , bad category for scores ranging from 41 to 55 , and very bad category for scores less than 40 .

Data analysis of the pretest and posttest scores was performed with N-gain which is used to determine the quality of student learning outcomes improvement before and after learning. N-gain can be calculated using the following formula:

$$
N \text {-gain }=\frac{S_{\text {posttest }}-S_{\text {pretest }}}{S_{\max }-S_{\text {pretest }}} \quad \text { (Meltzer, 2002) }
$$

Then, the criteria for classifying N-gain results were High for $N$-gain $\geq 0.7$; Medium for $0.7>N$-gain $\geq 0.3$; and Low for $N$-gain $<0.3$

\section{Results and Discussion}

The findings of research and discussion include validation of the PBL planning strategy, students' performance in the process of implementing the PBL approach, and student learning outcomes after carrying out chemistry instruction using the PBL approach in the context of tofu wastewater treatment.

Planning Strategy of Problem-Based Learning Approach in Chemistry Instruction with the Context of Tofu Wastewater Treatment

The PBL instructional planning strategy is structured in the Instructional Implementation Plan component. Table 2 shows the evaluation in the PBL instructional planning strategy in the context of tofu wastewater treatment.

Based on Table 1, instructional planning strategies on each component of the lesson plan in Tan type PBL instructional show an average score of 92.6. This means that the instructional planning strategy has met the evaluation criteria with very good categories. The detailed explanation for each component is as follows.

Table 1: PBL Instructional Planning Evaluation Score

\begin{tabular}{lccccccc}
\hline Components assessed & $\begin{array}{c}\text { The score of } \\
\text { the validator } \\
\text { (Scale } \mathbf{0 - 4 )}\end{array}$ & $\begin{array}{c}\text { Average } \\
\text { Score }\end{array}$ & $\begin{array}{c}\text { Score } \\
\text { (Scale } \\
\mathbf{0 - 1 0 0 )}\end{array}$ & $\begin{array}{c}\text { Standard } \\
\text { Deviation }\end{array}$ & $\begin{array}{c}\text { Score } \\
\text { Criteria }\end{array}$ \\
\cline { 2 - 5 } & $\mathbf{1}$ & $\mathbf{2}$ & 3 & & & & \\
\hline Learning Outcomes & 4 & 3 & 4 & 3.7 & 92.5 & 0.6 & VG \\
\hline Learning Materials & 4 & 4 & 4 & 4 & 100 & 0 & VG \\
\hline $\begin{array}{l}\text { Instructional } \\
\text { Strategies }\end{array}$ & 4 & 4 & 4 & 4 & 100 & 0 & VG \\
\hline $\begin{array}{l}\text { Media and Learning } \\
\text { Resources }\end{array}$ & 2 & 4 & 4 & 3.3 & 82.5 & 1.2 & G \\
\hline Instructional Steps & 3 & 3 & 4 & 3.3 & 82.5 & 0.6 & $\mathrm{G}$ \\
\hline Learning Evaluation & 4 & 4 & 4 & 4 & 100 & 0 & VG \\
\hline
\end{tabular}




\begin{tabular}{|c|c|c|c|c|c|c|c|}
\hline \multirow[t]{2}{*}{ Components assessed } & \multicolumn{3}{|c|}{$\begin{array}{l}\text { The score of } \\
\text { the validator } \\
\text { (Scale } 0-4 \text { ) }\end{array}$} & \multirow[t]{2}{*}{$\begin{array}{c}\text { Average } \\
\text { Score }\end{array}$} & \multirow[t]{2}{*}{$\begin{array}{l}\text { Score } \\
\text { (Scale } \\
0-100)\end{array}$} & \multirow[t]{2}{*}{$\begin{array}{l}\text { Standard } \\
\text { Deviation }\end{array}$} & \multirow[t]{2}{*}{$\begin{array}{l}\text { Score } \\
\text { Criteria }\end{array}$} \\
\hline & 1 & 2 & 3 & & & & \\
\hline Teaching Materials & 3 & 4 & 4 & 3.7 & 92.5 & 0.6 & VG \\
\hline Student Worksheet 1 & 4 & 4 & 3 & 3.7 & 92.5 & 0.6 & VG \\
\hline Student Worksheet 2 & 4 & 4 & 3 & 3.7 & 92.5 & 0.6 & VG \\
\hline Student Worksheet 3 & 4 & 4 & 3 & 3.7 & 92.5 & 0.6 & VG \\
\hline Student Worksheet 4 & 4 & 4 & 3 & 3.7 & 92.5 & 0.6 & VG \\
\hline Evaluation of Skills & 4 & 4 & 4 & 4 & 100 & 0 & VG \\
\hline \multirow[t]{2}{*}{ Evaluation of Attitude } & 4 & 4 & 4 & 4 & 100 & 0 & VG \\
\hline & \multicolumn{3}{|c|}{ Average } & 3.7 & 93.9 & 0.4 & VG \\
\hline
\end{tabular}

VG: Very Good

\section{Learning Outcomes (LO)}

Learning outcomes planning falls into the very good category (scored 90). This indicates that $\mathrm{LO}$ is following the required criteria, including learning outcomes that reveal students' words, competencies (cognitive domain, psychomotor, and affective) with operational verbs, chemistry content, learning conditions, and the level of quality performed (Uno, 2010). LO has been prepared following the demands of achieving High Order Thinking Skills (HOTS) which includes the ability to analyze, evaluate, and create (C4-C6). HOTS also requires critical and evaluative thinking, decision-making, and problem-solving (Widana, 2017). Students can obtain these higher-order thinking skills through learning with the PBL approach.

The learning outcomes formulation below is following the Tan type PBL syntax where learning outcomes 1 is described from Tan type PBL step 1. Learning outcomes 2-5 is described from step 2 while learning outcomes 6 and 7 are described from 3. In addition, learning outcomes 8 is the elaboration of step 4, and learning outcomes 9 is the elaboration of step 5. Besides, the cognitive learning outcomes formulation in learning with the PBL approach must include higher-order thinking skills. Learning outcomes on instructional are shown in Table 2. 
Table 2: Learning Outcomes on PBL Instructional in the Context of Tofu Wastewater Treatment

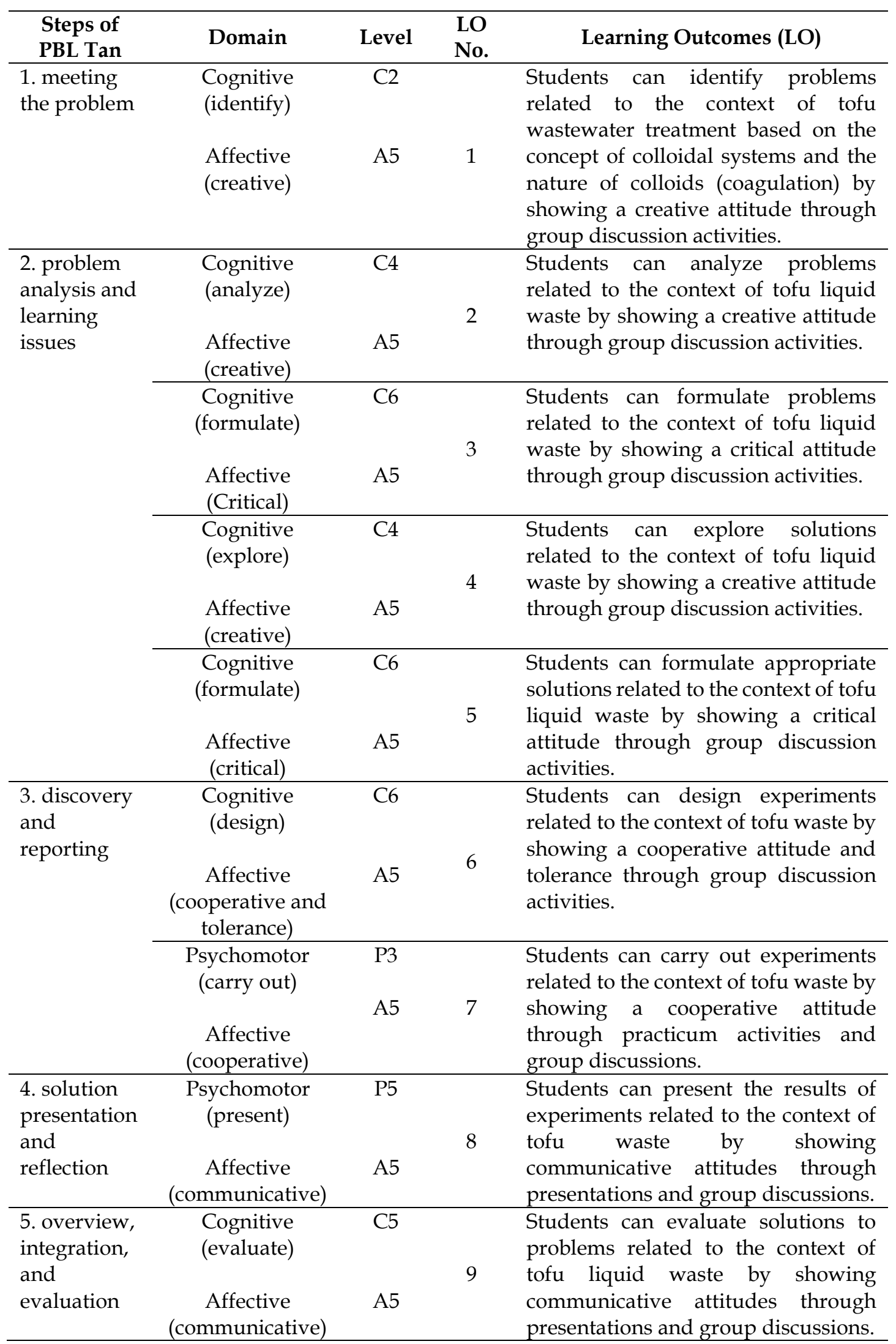


Cognitive competencies that will be achieved through learning outcomes are C2, C4, C5, and C6. There is one formulation of learning outcomes at cognitive level C2 (understanding), two formulas at level C4 (analyzing), one method at level C5 (evaluating), and three formulations at level C6 (creating). Thus, learning outcomes that have been prepared following the demands of achieving higher-order thinking skills or HOTS which must include the ability to analyze, evaluate, and create. HOTS also requires critical and evaluative thinking, decision-making, and problem-solving. Students can obtain these higher-order thinking skills through learning with the PBL approach (Widana, 2017).

\section{Learning Materials}

The planning of learning materials belongs to a very good category (scored 100). This indicates that learning material has met the required criteria, such as containing relevant prerequisite material and core material consisting of facts, concepts, principles, and procedures (Depdikbud, No. 21, 2016). The selected prerequisite material is following the materials needed before learning. Then, the selected core material is following the required concepts for problemsolving to be done.

Some prerequisite concepts needed in studying tofu wastewater treatment were the definition of waste, homogeneous and heterogeneous mixture, electrolyte solution, and a dispersion system (true solution, colloid, and suspension). The core concepts developed in handling tofu wastewater were turbid tofu liquid waste (factual knowledge), colloidal system, colloidal properties (coagulation), and precipitation reaction as conceptual knowledge. Another core concept was tofu coagulation tofu liquid waste experiment with tamarind coagulant as procedural knowledge.

\section{Instructional Strategies}

The planning of instructional strategies falls into the very good category (scored 100). This indicates that the instructional strategy is following the required criteria, such as containing models, approaches, and learning methods. Therefore, the application of learning methods can realize the learning process so that students can achieve learning outcomes that have been planned (Depdikbud, No. 22, 2016). PBL steps used is a modified Tan type PBL syntax, where the syntax is no longer only refers to the final results obtained by students. Still, it refers to the process by students to get the final results following the demands of the 2013 chemistry curriculum. Instructional models, instructional approaches, and instructional methods in instructional strategies are considered to be following the Tan type PBL learning plan.

\section{Media and Learning Resources}

The planning of media and learning resources falls into a good category (scored 83.2). This indicates that the media and learning resources are following the required criteria, such as learning media that are used function as a tool for the delivery of learning materials and learning resources in the form of books and other learning resources that have been relevant (Depdikbud, No. 22, 2016). 
The media used are PowerPoint Templates (PPt) of tofu liquid waste handling and worksheets. Those learning media are easy to use and can help students to understand the learning material. Then, the learning resources used can help students to find and determine solutions to problems for handling tofu liquid waste.

\section{Instructional Steps}

The planning of instructional steps formulated by chemistry teachers falls into a good category (scored 83.2). This indicates that the instructional steps are following the required criteria, such as student-centered, includes three activities (introduction, core, and closing), shows the expected achievement of $\mathrm{LO}$, and the time allocated is in accordance with the $\mathrm{LO}$ that need to be achieved (Depdikbud, No. 22, 2016).

Instructional is designed for four meetings, each requires $2 \times 45$ minutes. The first meeting is designed to present step 1 (identifying problems) and step 2 (analyzing and formulating problems) of the Tan type PBL stages. The second meeting is designed to offer step 3 (designing problem-solution). While step 4 (implementing problem solution) is presented in the third meeting and step 5 (presenting, reporting, evaluating, and reflecting) is in the fourth meeting.

In the introduction activities, there are several steps, namely, 1) preparing students psychologically and physically by greeting students, praying and asking how students are doing, 2) giving apperception by asking questions that link previous knowledge with the material to be learned, 3) motivating students by providing phenomena in daily life related to teaching material, 4) explaining learning objectives or essential competencies to be achieved from learning and 5) explaining learning objectives or essential skills to be obtained from education. All introduction stages are illustrated in the learning steps in the lesson plan above (Depdikbud, No. 22, 2016).

After the introduction is the core activity which is carried out following the 5 steps of Tan type PBL. The description of the core activities with the Tan type PBL step will be discussed in the following paragraphs. The core activities at the first meeting are learning using step 1 and step 2, namely, students identify between tofu liquid and solid waste that can be harmful to the environment. After recognizing the problem that can emerge from the tofu wastewater, students are guided to formulate one issue that will need a solution.

In the second meeting, students carry out learning using step 3 namely, students design solutions to problems by determining one solution to be employed and followed by designing experiments to solve problems with the specified solutions.

Learning using step 4 is applied in the third meeting. Students implement solutions to problems or solve problems through experiments from previous experimental designs. The results of applying this problem help students to find out whether the solution is used correctly and whether problem-solving is successful. 
The core activity in the fourth meeting employs step 5 namely, students present (report), evaluate, and reflect on problem-solving. Students report the results of attempted problem solving through a presentation, then conduct an evaluation and reflection on the resolution that has been applied.

After the core activities are finished, it ends with the closing activity. The steps in the closing activity are evaluating the series of learning activities along with the results obtained, providing feedback on the learning process and results, and informing the plans for further learning activities (Tan, 2003; Depdikbud, No. 22, 2016).

\section{Learning Evaluation}

Planning for learning evaluation falls into the very good category (scored 100). This indicates that the learning evaluation is following the required criteria, such as learning evaluation carried out at the end of the learning process which includes the evaluation of attitude, skills, and knowledge, as well as the evaluation methods and tools used are relevant to the aspects of attitudes, skills, and experience (Depdikbud, No. 23, 2016).

\section{Teaching Materials}

The planning of teaching materials belongs to a very good category (91.6). This indicates that the teaching material has met the required criteria, such as selfinstructional, self-contained, stand-alone, and user-friendly. Self-instructional means that teaching material can be useful and used by students individually and autonomous means teaching material that is compiled contains all content or theory of subjects grouped in one competency unit and a dissertation with sub-competencies. While stand-alone means that the teaching material that has been prepared can stand alone and does not need support from other teaching materials because the teaching material already includes all required subject matter. Last, user-friendly means that teaching material that has been prepared is easy to use by students through simple language as well as the easy and general term (Lestari, 2013).

\section{Student Worksheet}

Worksheet planning falls into the very good category (91.6). This indicates that the worksheets are following the primary elements required, such as a title, competencies or learning outcomes-oriented, supporting information (such as articles) availability, tasks or work steps availability, and reports that must be done (Prastowo, 2011). The spreadsheets that have been prepared refer to learning outcomes, subject matter, and Tan PBL steps. Thus, the questions in the spreadsheet can guide students to achieve learning outcomes following the PBL learning stages and can help students to solve the problem of handling tofu liquid waste ( $\mathrm{Li} \& \mathrm{Du}, 2015)$.

\section{Skill Evaluation}

Planning for the skill evaluation falls into the very good category (scored 100). This indicates that skill evaluation is following the required criteria, such as the skill evaluation used to measure the achievement following competencies or 
learning outcomes. The skill evaluation requires students to demonstrate specific learning outcomes, as well as instruments used in the form of checklists or rating scales (Ditjenpendas, 2015). The skills that emerge are students able to carry out experiments and present the results of operations, and these skills are must-have skills in the 21st century where students are required to have good work and communication skills (Griffin \& Care, 2015). Thus, through learning with the PBL approach can help students to hone these skills.

\section{Attitude Evaluation}

Attitude evaluation planning falls into the very good category (scored 100). This indicates that the attitude evaluation is following the required criteria in which the evaluation is in line with the formulation of learning outcomes with the evaluation technique that is suitable for attitude evaluation (Ditjenpendas, 2015). Attitudes that are expected to arise are creative, critical, cooperative, tolerance, and communicative attitudes which are also skills that students must-have in the 21st century (Griffin \& Care, 2015). Thus, learning with the PBL approach can help students to hone these attitudes.

\section{Students' Performance in the Process of Implementing Problem-Based Learning Approaches with the Context of Tofu Wastewater Treatment} Students' performance evaluation is assessed using the worksheet. In the learning implementation, students are divided into six groups, so that the evaluation of students' performance is carried out for each group.

\section{Step 1: Identifying Problems}

In this step, students would be faced with problems. The problems that arise would act as a stimulus to build and expand the realistic context that students might face in the future (Tan, 2003). The following Table 3 shows the average grade of students in step 1: identifying problems.

Table 3: Students' Grades in Step 1: Identifying Problems

\begin{tabular}{cc}
\hline Group & Score \\
\hline 1 & 83.3 \\
\hline 2 & 91.7 \\
\hline 3 & 91.7 \\
\hline 4 & 91.7 \\
\hline 5 & 91.7 \\
\hline 6 & 83.3 \\
\hline $\begin{array}{l}\text { Average score/standard } \\
\text { deviation }\end{array}$ & $88.9 /(4.3)$ \\
\hline
\end{tabular}

Based on Table 3, groups 1 and 6 scored 83.3 in the good category, groups 2, 3, 4 , and 5 scored 91.7 with a very good category. The average score of students in the step of identifying problems is 88.9 , meaning that students can identify problems very well. Therefore, it can be stated that the performance of students in the step of identifying problems is classified as very good. 


\section{Step 2: Analyzing and Formulating Problems}

In the step of analyzing and formulating questions, students will analyze and develop one issue related to tofu wastewater treatment that will be sought for resolution. Students discuss the issues that arise and find information from various sources, then determine one problem statement that will be asked for resolution (Tan, 2003).

Table 4 below shows the average grade of students in step 2: analyzing and formulating problems.

Table 4: Students' Grades in Step 2: Analyzing Problems

\begin{tabular}{cc}
\hline Group & Score \\
\hline 1 & 75 \\
\hline 2 & 75 \\
\hline 3 & 75 \\
\hline 4 & 75 \\
\hline 5 & 100 \\
\hline 6 & 75 \\
\hline $\begin{array}{c}\text { Average score/standard } \\
\text { deviation }\end{array}$ \\
\hline
\end{tabular}

Based on Table 4, groups 1, 2, 3, 4, and 6 scored 75 in the good category, while group 5 scored 100 with a very good category. The average score of the group in the step of analyzing and formulating problems is 79.2, meaning that students can analyze and develop questions properly. So it can be concluded that the students' performance in the step of analyzing and formulating questions is classified as useful.

\section{Step 3: Designing Problem Solutions}

After obtaining a problem statement, students will design a problem solution. At this stage, students find solutions to problem-solving, then students are guided to formulate problem-solving strategies from the solutions obtained, finally, students in their groups report the problem-solving findings (Tan, 2003; Lin, Taiwan, Liang, 2014). The following Table 5 shows the students' average grade in step 3: designing problem solutions.

Table 5: Students' Grades in Step 3: Designing Problem Solutions

\begin{tabular}{cc}
\hline Group & Score \\
\hline 1 & 84.8 \\
\hline 2 & 97 \\
\hline 3 & 88 \\
\hline 4 & 91 \\
\hline 5 & 91 \\
\hline 6 & 97 \\
\hline Average/standard deviation & $91.5 / 4.9$ \\
\hline
\end{tabular}


Based on Table 4, group 1 scored 84.8 with the good category. Group 3 scored 88 with a very good grade, groups 4 and 5 scored 91 with the very good category, while groups 2 and 6 scored 97 with the very good grade. The average score of the group in the step of designing problem solutions is 91.5, meaning that students can create problem solutions very well. So it can be concluded that the students' performance in the design step of problem solutions is classified as very good.

\section{Step 4: Implementing Solution}

After formulating the problem solution and designing a test for problemsolving, the next step is implementing the problem solution. At this stage, students will conduct tests to solve problems that are carried out based on test designs that have been made by students.

In this step, students are asked to answer six items, the answers to which are poured into LKS-3. In the first item, students are asked to make a table of test results, in items number 2-4, students are asked to explain the material and ways used to solve problems. In contrast, items number 5 and 6 ask students to explain the working principle of the method used for problem-solving.

All items asked in these LKS-3 were:

Item 1: Based on the experiments that you have done, make a table of observations of tests that you have done! (Write the data before and after treatment)

Item 2: What materials are used in handling tofu wastewater?

Item 3: What is the substance called for handling tofu wastewater? What are the ingredients?

Item 4: Handling of tofu liquid waste is based on one of the concepts of colloidal nature, what is the method called? Explain!

Item 5: What is the working principle used for handling this liquid waste? Explain!

Item 6: How does tamarind coagulate colloidal particles in tofu wastewater? Write down their chemical reaction!

Table 6 below is an example of students' authentic answers to the six items. Their answers are still in Indonesian. Therefore, the researchers translate students' answers into English in order to be easily understood.

Table 6: Authentic students' answers to the Items in LKS-3

\begin{tabular}{|c|c|c|}
\hline $\begin{array}{l}\text { Items } \\
\text { Number }\end{array}$ & \multicolumn{2}{|c|}{ Authentic Students' Answers } \\
\hline \multirow[t]{4}{*}{1} & \multicolumn{2}{|r|}{ Group 4} \\
\hline & \multicolumn{2}{|r|}{ LIMBAH } \\
\hline & Schelum Koagulan. & $\begin{array}{l}\text { - Tidar ada endepan } \\
\text { - Kemih }\end{array}$ \\
\hline & Sesudan Koagulas: & $\begin{array}{l}\text { Ada endapan } \\
\text { Sermb }\end{array}$ \\
\hline \multirow[t]{2}{*}{2} & \multicolumn{2}{|r|}{ Group 2} \\
\hline & \multicolumn{2}{|c|}{ Serbuk Bujs Asam Jawa } \\
\hline
\end{tabular}




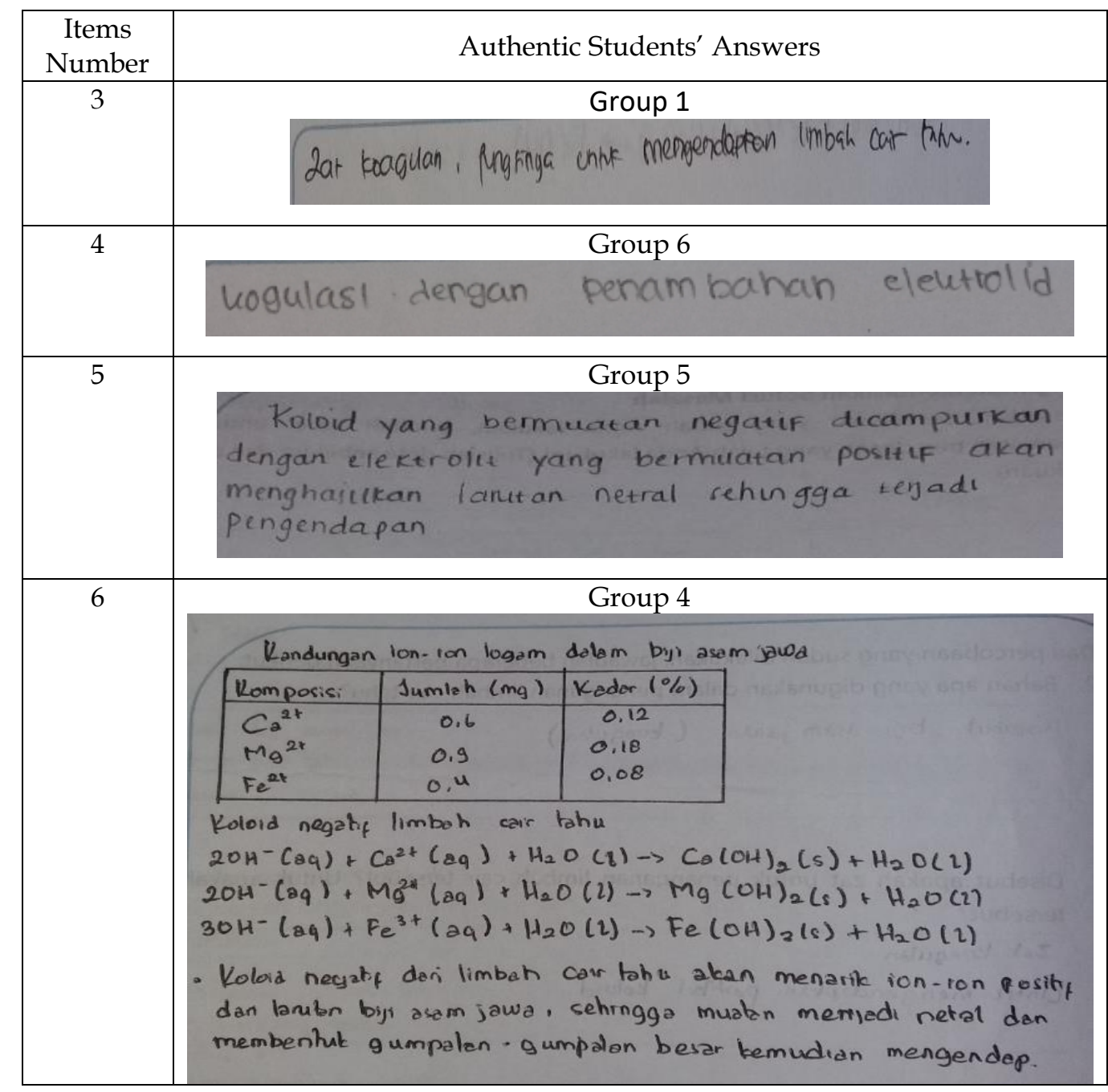

Table 7 below summarizes the answers of each group to each of the items in the student worksheet-3 (LKS-3)

Table 7: Students' Answers to item 1 in LKS-3

\begin{tabular}{|c|c|c|c|c|}
\hline & \multirow{2}{*}{\multicolumn{4}{|c|}{ The Answer }} \\
\hline Groups & & & & \\
\hline \multirow{4}{*}{$1,2,3,4,5$, and 6} & \multirow{2}{*}{ No. } & \multirow{2}{*}{ Treatment of waste } & \multicolumn{2}{|c|}{ Observation } \\
\hline & & & turbidity & precipitation \\
\hline & 1 & $\begin{array}{l}\text { before the addition } \\
\text { of tamarind }\end{array}$ & turbid & no precipitation \\
\hline & 2 & $\begin{array}{l}\text { after the addition of } \\
\text { tamarind }\end{array}$ & $\begin{array}{c}\text { turbidity level } \\
\text { decreases (clearer) }\end{array}$ & $\begin{array}{c}\text { there is } \\
\text { precipitation } \\
\text { (white) }\end{array}$ \\
\hline
\end{tabular}

Based on Table 7, each group discusses their findings, then writes the results of the test in tabular form. The maximum score for item number 1 is 4 , with four keywords of "turbid", "no precipitation", "turbidity level decreases", and "white precipitation". All groups answered correctly and obtained a score of 4 by mentioning the four expected keywords. 
Just like the answer given to item 1, all groups gave the same answer to item 2, that the chemical used to handle tofu liquid waste was tamarind seed powder. The maximum score for item number 2 is 1, with one keyword, namely tamarind seed powder. It turns out that all answers in each group are correct.

Likewise, all groups give the same answer to item 3, where the chemical terminology given to tamarind seed powder is called "coagulant", the material "functions to coagulate or precipitate colloids in tofu wastewater". The maximum score for item number 3 is 3 , with three keywords, namely Coagulant: its function is to thicken the colloids particle in tofu liquid waste. It turns out that all answers in each group are correct.

Two types of answers are given to item 4 . Students in groups 1, 2, 3, 5, and 6 answer, "the coagulation is the process of deposition or agglomeration of colloidal particles." The answer from group 4 is more complete, where "coagulation was interpreted as the process of deposition or clumping of colloidal particles through mixing colloids with chemicals that have different electrical charges or by adding electrolytes". The maximum score for item number 4 is 4 , with four keywords, namely "The method used is coagulation which is the process of enlarging the size of colloidal particles (coagulation of colloidal particles) by coagulants." It turns out that all groups got a score of 3 because they could only put forward the three expected keywords.

Three types of answers are given to item 5, in which group 1 answers, "when the negative charge from colloids mixes with the positive charge from the electrolyte, a precipitation reaction occurs". The answer from groups 2, 3, 5, and 6 is that when colloids are mixed into the electrolyte, the negative charge of the colloid will be bound by the positive ion charge of the electrolyte so that the charge becomes neutral and causes deposition (coagulation). The answer of group 4 stated that the meeting of the negative charge from the colloid and the positive charge from the electrolyte makes the charge neutral and precipitation occur. The maximum score for item number 5 is 6, with six keywords, namely "The working principle used is coagulation in the presence of electrolytes, that is if negatively charged colloids are mixed with an electrolyte solution, then the positive ions from the electrolyte solution will be attracted by negatively charged colloids, so the charge becomes neutral and causes coagulation or settles." Based on these criteria, groups 1 and 4 get a score of 4 because they can express four principles, while groups 2, 3, 5, and 6 get a score of 5 because they can learn the 5 required criteria.

Four types of answers are given to item 6 . The answer of group 1 is stated as follows

Negatively charged colloids mixed with positive electrolytes $\mathrm{Ca}^{2+}, \mathrm{Mg}^{2+}$ and $\mathrm{Fe}^{3+}$ produce a precipitating reaction:

$2 \mathrm{OH}^{-}(a q)+\mathrm{Ca}^{2+}(a q)+\mathrm{H}_{2} \mathrm{O}(\mathrm{l}) \rightarrow \mathrm{Ca}(\mathrm{OH})_{2}(\mathrm{~s})+\mathrm{H}_{2} \mathrm{O}(\mathrm{l})$

$2 \mathrm{OH}^{-}(\mathrm{aq})+\mathrm{Mg}^{2+}(\mathrm{aq})+\mathrm{H}_{2} \mathrm{O}(\mathrm{l}) \rightarrow \mathrm{Mg}(\mathrm{OH})_{2}(\mathrm{~s})+\mathrm{H}_{2} \mathrm{O}(\mathrm{l})$

$3 \mathrm{OH}^{-}(\mathrm{aq})+\mathrm{Fe}^{3+}(\mathrm{aq})+\mathrm{H}_{2} \mathrm{O}(\mathrm{l}) \rightarrow \mathrm{Fe}(\mathrm{OH})_{3}(\mathrm{~s})+\mathrm{H}_{2} \mathrm{O}(\mathrm{l})$ 
Groups 2, 4, and 5 answer that

The ions from tamarind $\mathrm{Ca}^{2+}, \mathrm{Mg}^{2+}$ and $\mathrm{Fe}^{3+}$ are drawn by negative colloids $\left(\mathrm{OH}^{-}\right)$ from tofu liquid waste, so that the charge will become neutral and form large lumps and then precipitate. The chemical equation is:

$2 \mathrm{OH}-(a q)+\mathrm{Ca}^{2+}(a q)+\mathrm{H}_{2} \mathrm{O}(\mathrm{l}) \rightarrow \mathrm{Ca}(\mathrm{OH})_{2}(\mathrm{~s})+\mathrm{H}_{2} \mathrm{O}(\mathrm{l})$

$2 \mathrm{OH}^{-}(\mathrm{aq})+\mathrm{Mg}^{2+}(a q)+\mathrm{H}_{2} \mathrm{O}(\mathrm{l}) \rightarrow \mathrm{Mg}(\mathrm{OH})_{2}(\mathrm{~s})+\mathrm{H}_{2} \mathrm{O}(\mathrm{l})$

$3 \mathrm{OH}-(a q)+\mathrm{Fe}^{3+}(a q)+\mathrm{H}_{2} \mathrm{O}(\mathrm{l}) \rightarrow \mathrm{Fe}(\mathrm{OH})_{3}(\mathrm{~s})+\mathrm{H}_{2} \mathrm{O}(\mathrm{l})$

Groups 3 states that

The negative-charged colloid (tofu water waste) is mixed into the electrolyte solution, the ions such as $\mathrm{Ca}^{2+}, \mathrm{Mg}^{2+}$, and $\mathrm{Fe}^{3+}$ contained in the tamarind seeds will be pulled by the colloidal negative charge so that the charge becomes neutral. As a result, the tofu liquid waste particles settle.

$2 \mathrm{OH}-(a q)+\mathrm{Ca}^{2+}(a q)+\mathrm{H}_{2} \mathrm{O}(\mathrm{l}) \rightarrow \mathrm{Ca}(\mathrm{OH})_{2}(\mathrm{~s})+\mathrm{H}_{2} \mathrm{O}(\mathrm{l})$

$2 \mathrm{OH}^{-}(\mathrm{aq})+\mathrm{Mg}^{2+}(\mathrm{aq})+\mathrm{H}_{2} \mathrm{O}(\mathrm{l}) \rightarrow \mathrm{Mg}(\mathrm{OH})_{2}(\mathrm{~s})+\mathrm{H}_{2} \mathrm{O}(\mathrm{l})$

$3 \mathrm{OH}^{-}(a q)+\mathrm{Fe}^{3+}(a q)+\mathrm{H}_{2} \mathrm{O}(\mathrm{l}) \rightarrow \mathrm{Fe}(\mathrm{OH})_{3}(\mathrm{~s})+\mathrm{H}_{2} \mathrm{O}(\mathrm{l})$

Groups 6 provide answers that

The reaction equation is as follows:

$2 \mathrm{OH}-(a q)+\mathrm{Ca}^{2+}(a q)+\mathrm{H}_{2} \mathrm{O}(\mathrm{l}) \rightarrow \mathrm{Ca}(\mathrm{OH})_{2}(\mathrm{~s})+\mathrm{H}_{2} \mathrm{O}(\mathrm{l})$

$2 \mathrm{OH}^{-}(a q)+\mathrm{Mg}^{2+}(a q)+\mathrm{H}_{2} \mathrm{O}(\mathrm{l}) \rightarrow \mathrm{Mg}(\mathrm{OH})_{2}(\mathrm{~s})+\mathrm{H}_{2} \mathrm{O}(\mathrm{l})$

$3 \mathrm{OH}^{-}(\mathrm{aq})+\mathrm{Fe}^{3+}(\mathrm{aq})+\mathrm{H}_{2} \mathrm{O}(\mathrm{l}) \rightarrow \mathrm{Fe}(\mathrm{OH})_{3}(\mathrm{~s})+\mathrm{H}_{2} \mathrm{O}(\mathrm{l})$

The maximum score for item number 6 is 8 , with eight keywords as follows:

In the tamarind seeds contained metal ions $\mathrm{Ca}^{2+}, \mathrm{Mg}^{2+}$ and $\mathrm{Fe}^{3+}$,
and tofu liquid waste are negatively charged colloid.
Negative colloids from tofu liquid waste will attract positive
ions from the tamarind seed solution so that the charge will
become neutral and form large lumps and then settle. The
equation for the reaction that occurs between $\mathrm{Ca}^{2+}, \mathrm{Mg}^{2+}$, and $\mathrm{Fe}^{3+}$
ions, and $\mathrm{OH}-$ ions from negative colloids from tofu wastewater is
as follows:
$2 \mathrm{OH}^{-}(a q)+\mathrm{Ca}^{2+}(a q)+\mathrm{H}_{2} \mathrm{O}(\mathrm{l}) \rightarrow \mathrm{Ca}(\mathrm{OH})_{2}(s)+\mathrm{H}_{2} \mathrm{O}(\mathrm{l})$
$2 \mathrm{OH}(a q)+\mathrm{Mg}^{2+}(a q)+\mathrm{H}_{2} \mathrm{O}(\mathrm{l}) \rightarrow \mathrm{Mg}(\mathrm{OH})_{2}(s)+\mathrm{H}_{2} \mathrm{O}(\mathrm{l})$
$3 \mathrm{OH}(a q)+\mathrm{Fe}^{3+}(a q)+\mathrm{H}_{2} \mathrm{O}(\mathrm{l}) \rightarrow \mathrm{Fe}(\mathrm{OH})_{3}(s)+\mathrm{H}_{2} \mathrm{O}(l)$

Based on these criteria, group 1 gets a score of 6 , groups 2, 4, and 5 get a score of 8 , group 3 gets a score of 8 , while group 6 gets a score of 4 .

The following Table 8 shows the average grade of students in step 4: implementing the problem solution. Based on table 8, group 6 scored 77 in the good category. Group 1 scored 80.8 in the good category, group 4 composed 88.5 in the very good grade category, and groups 2,3, and 5 scored 92.3 in the very good category. The average score of the group in the step of implementing the solution is 87.2 , meaning that students can implement solutions to problems well. Therefore, students' performance in the step of implementing the problem solution is quite good. 
Table 8: Students' Grades in Step 4: Implementing Problem Solutions

\begin{tabular}{cc}
\hline Group & Score \\
\hline 1 & 80.8 \\
\hline 2 & 92.3 \\
\hline 3 & 92.3 \\
\hline 4 & 88.5 \\
\hline 5 & 92.3 \\
\hline 6 & 77 \\
\hline Average score/standard deviation & $87.2 / 6.7$ \\
\hline
\end{tabular}

\section{Step 5: Presenting (Reporting), Evaluating and Reflecting Problem Resolution}

In this step, students will present the results of problem-solving and then the teacher will clarify or confirm the problem solving offered by students. Besides, teachers will also confirm students' questions or doubts about solving problems to avoid misconceptions. Each group members also evaluate how they, as students, become problem solvers, independent students, and team members (Tan, 2003; Machika \& Abrahams, 2014). Table 9 below shows the average grade of students in step 5: presenting (reporting) evaluating and reflecting problem-solving.

Table 9: Students' Score in Step 5: Presenting (Reporting) Evaluating and Reflecting Problem Resolution

\begin{tabular}{cc}
\hline Group & Score \\
\hline 1 & 70.7 \\
\hline 2 & 85.4 \\
\hline 3 & 80.5 \\
\hline 4 & 83.0 \\
\hline 5 & 75.6 \\
\hline 6 & 70.7 \\
\hline Average score/standard deviation & $77.7 / 6.3$ \\
\hline
\end{tabular}

Based on table 9, groups 1 and 6 scored 70.7 with sufficient category, group 5 scored 75.6 with good category, group 3 scored 80.5 with good category, groups 4 and 5 scored 83 and 85.4 respectively with a good category. The average score of the group in the step of presenting (reporting), evaluating, and reflecting a problem solution is 77.7, meaning that students do well in this category. So it can be concluded that the students' performance in the step of presenting (reporting), evaluating, and reflecting on problem-solving classified as useful.

The following Table 10 shows the average score obtained by students in each learning step with the Tan type PBL approach.

Table 10: Students' Score in Step 1 - Step 5 Tan Type PBL Approach

\begin{tabular}{cc}
\hline Step & Score \\
\hline 1 & 88.9 \\
\hline 2 & 79.1 \\
\hline 3 & 91.5
\end{tabular}




\begin{tabular}{cc}
\hline 4 & 87.2 \\
\hline 5 & 77.7 \\
\hline Average score/standard deviation & $84.9 / 6.1$ \\
\hline
\end{tabular}

Table 10 shows the average score of students' performance in each learning step with Tan type PBL is 84.9 which belongs to a good category. So that students' performance in implementing the PBL approach in learning with the context of tofu wastewater treatment can be classified in the good category.

\section{Students' Learning Outcomes after Carrying Out Chemistry Instructional Using Problem-Based Learning Approach in the Context of Tofu Wastewater Management}

Learning outcomes are divided into three categories, namely cognitive, affective, and psychomotor domains (Anderson \& Krathwohl, 2001). Thus, the evaluation of learning outcomes was carried out in all three fields with the following explanation:

\section{Students' Learning Outcomes on Cognitive Aspects}

Students' cognitive learning outcomes (knowledge) are measured from the results of students' pretest and posttest (appendix). The pretest and posttest questions given are the same, the issues consist of eight items regarding the meaning of tofu wastewater treatment in the form of multiple-choice questions. The basic chemistry and technical concepts of tofu wastewater treatment that are tested include the type of tofu waste, the stages of making tofu, the formulation of the problem for investigating tofu waste handling, tofu liquid waste handling by coagulation, the chemistry principle of adding alum or tamarind into tofu liquid waste, chemical calculations, and steps of handling tofu liquid waste.

Figure 1 below shows the results of the pretest regarding the context of tofu wastewater treatment.

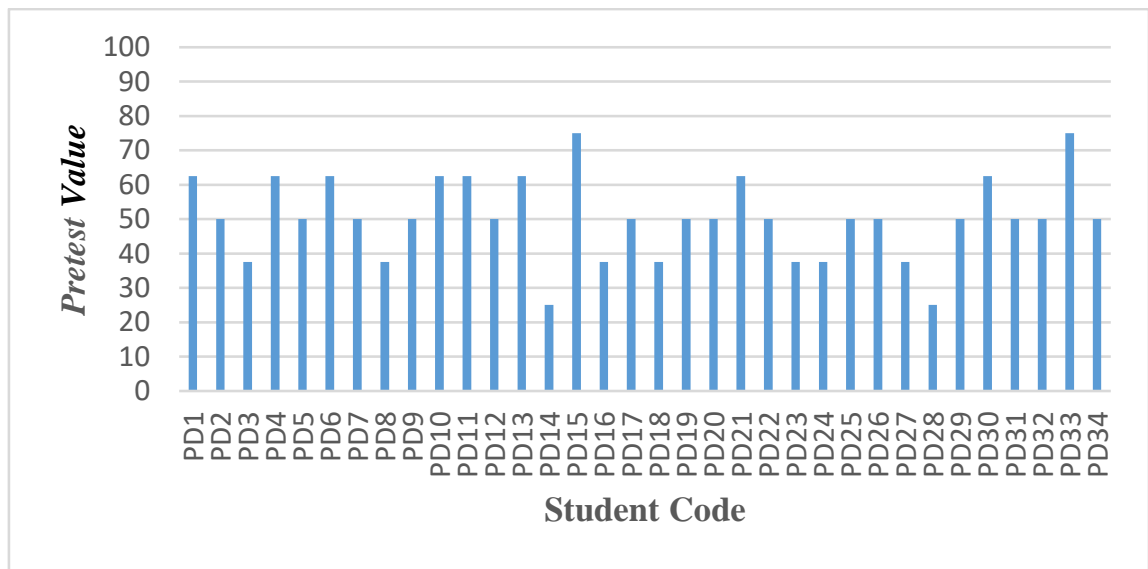

Figure 1: Students' Pretest Score in the Context of Tofu Liquid Waste Management

Students' pretest learning outcomes are still classified as a low category because there are still many who have not yet reached the minimum score of 75. The average students' pretest score in the context of tofu liquid waste 
handling is 50 which belongs to less or low category. The implementation of the pretest aims to find out students' fundamental knowledge of the material to be learned.

After the pretest, students are given treatment by giving knowledge about how to handle tofu liquid waste using Tan's PBL approach. Instruction is carried out four times, in the last meeting, posttest was held to find out students' learning outcomes in the context of tofu liquid waste handling with Tan type PBL approach. Figure 2 below shows a graph of students' post-test scores.

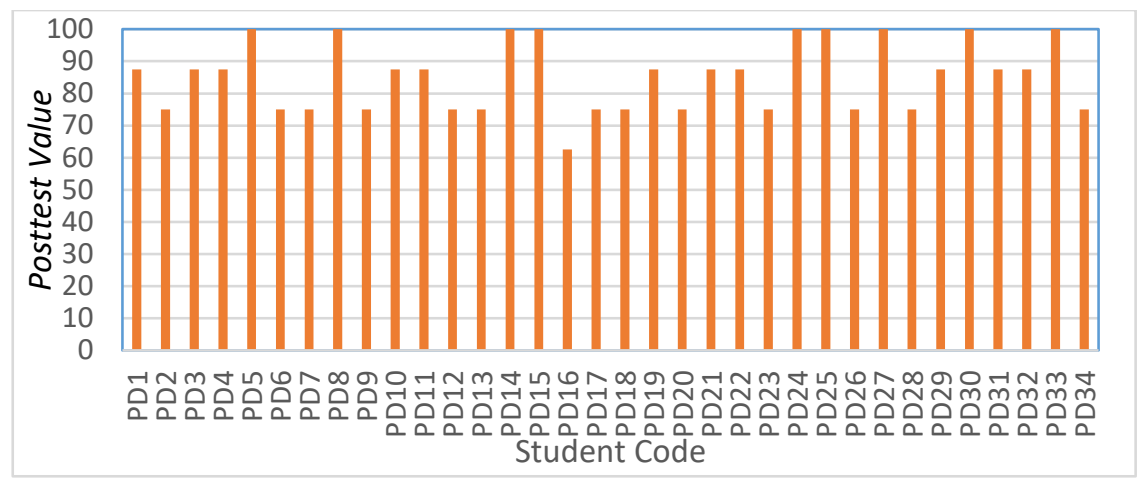

Figure 2: Students' Posttest Score in the Context of Tofu Liquid Waste Management

Based on Figure 2, students' posttest results are higher when compared to pretest results. Overall, there is an increase in students' learning outcomes, wherein the posttest results there are $97 \%$ of students who have achieved minimum scores (75), with an average posttest score of 85.3 For more details, the comparison of the pretest and posttest scores is illustrated in Figure 3 below.

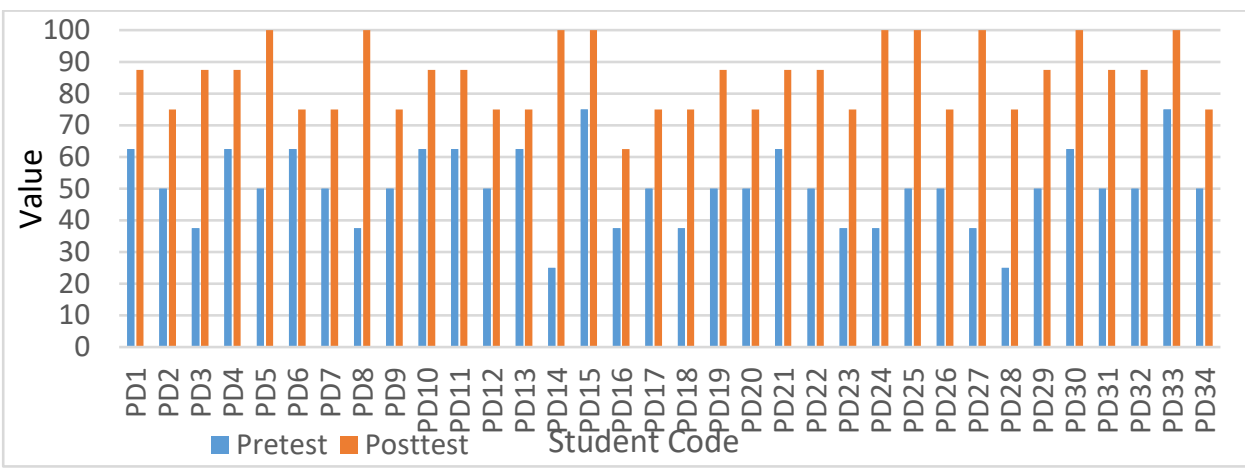

Figure 3: Comparison of Students' Pretest and Posttest Score in the Context of Handling the Tofu Liquid Waste

Based on Figure 3, there is an increase in students' cognitive learning outcomes after carrying out learning with the PBL approach. The growth shows that students understand the learning material easier when using the PBL approach. 
The improvement of students' learning outcomes before (pretest) and after learning (posttest) was tested with N-gain using Microsoft Excel 2016. This test is used to find out how the influence of the PBL approach on improving students' cognitive learning outcomes after learning.

Based on the test results obtained, the average score of N-gain of the students' learning outcomes is 0.67, and there is an increase in students' learning outcomes between pretest and posttest with the medium category. Thus, it can be concluded that learning with the Tan type problem-based learning (PBL) approach can improve students' cognitive learning outcomes. Therefore, the quality of understanding of the chemical concepts in PBL can be achieved well when the teacher functions as a facilitator (Isa et al., 2015; Li \& Chen, 2018).

\section{Students' Learning Outcomes on Affective Aspects}

The evaluation of students' learning outcomes on affective (attitude) and psychomotor (skills) is carried out by the teacher to the group of students during the learning process using the attitude and skill observation sheet instrument. The attitudes and skills observed are based on $21^{\text {st-century skills }}$ needed by students, including thinking skills and skills in the use of technology, information, and literacy (Griffin \& Care, 2015). The attitudes observed are creative, critical, cooperative, tolerant, and communicative, while the observed skills are the students' skills when conducting experiments. Thus, the belief that arises from PBL learning demands the empowerment of combinatorial thinking following Hidayati et al. (2019).

Table 11 shows the indicators of competency assessed.

Table 11: Indicators of Competency in Attitude Aspects being Assessed

\begin{tabular}{|c|c|}
\hline $\begin{array}{c}\text { Attitude Aspects } \\
\text { Assessed }\end{array}$ & Evaluation Criteria \\
\hline Creativity & $\begin{array}{l}\text { 1. Finding and detailing the adverse effects of tofu solid and } \\
\text { liquid waste } \\
\text { 2. Finding ideas about problems related to the context of tofu } \\
\text { liquid waste management } \\
\text { 3. Looking for problem-solving solutions associated with the } \\
\text { meaning of tofu wastewater treatment from various } \\
\text { references } \\
\text { 4. Finding several problem-solving solutions related to the } \\
\text { context of tofu wastewater treatment }\end{array}$ \\
\hline Critical & $\begin{array}{l}\text { 1. Determining which waste is dangerous and will be dealt } \\
\text { with and resolved (between liquid waste and solid waste) } \\
\text { 2. Determining a formulation of the problem related to the } \\
\text { context of handling tofu wastewater to be resolved } \\
\text { 3. Comparing the predicted solutions to issues that can be } \\
\text { used to treat tofu liquid waste } \\
\text { 4. Determining one tofu liquid waste management solution } \\
\text { that is suitable for solving the problem from the results of } \\
\text { the investigation }\end{array}$ \\
\hline
\end{tabular}




\begin{tabular}{ll}
\hline & $\begin{array}{l}\text { 1. Actively involved in designing experiments on tofu liquid } \\
\text { waste management }\end{array}$ \\
2. Finding a way to overcome differences of opinion in \\
designing experiments on tofu liquid waste management \\
3. Actively involved in conducting experiments on tofu liquid \\
waste management \\
4. Conducting experimental tasks in handling tofu wastewater \\
according to the agreement made
\end{tabular}

Table 12 shows the average score of attitude for each group of students.

Table 12: Results of Evaluation of Students' Attitude Aspects

\begin{tabular}{ccccccc}
\hline \multirow{2}{*}{ Group } & \multicolumn{7}{c}{ Attitudes Aspects Assessed } & Average \\
\cline { 2 - 8 } & Creativity & Critical & Cooperation & Tolerance & Communicative & \\
\hline 1 & 75 & 100 & 100 & 100 & 75 & 90 \\
\hline 2 & 75 & 100 & 100 & 100 & 100 & 95 \\
\hline 3 & 75 & 100 & 100 & 100 & 100 & 95 \\
\hline 4 & 75 & 100 & 100 & 100 & 75 & 90 \\
\hline 5 & 100 & 100 & 100 & 100 & 100 & 100 \\
\hline 6 & 100 & 100 & 100 & 100 & 75 & 95 \\
\hline Average/StDev & $83.3 / 12.9$ & $100 / 0.0$ & $100 / 0.0$ & $100 / 0.0$ & $87.5 / 13.7$ & $94.2 / 3.8$ \\
\hline Category & G & VG & VG & VG & VG & VG \\
\hline G = Good; VG = Very Good & & & & &
\end{tabular}

$\mathrm{G}=$ Good; $\mathrm{VG}=$ Very Good

Based on Table 12, groups 1, 2, 3, and 4 scored 75 with good category, while groups 5 and 6 scored 100 with a very good category. This means that groups $1,2,3$, and 4 have been able to think creatively to find and elaborate the negative impacts of solid and tofu liquid waste. Besides, they are able to find solutions to problems related to the context of handling tofu liquid waste and wastewater treatment. However, the group has not been able to find the idea 
for the problem related to the meaning of tofu wastewater treatment completely. As for groups 5 and 6, they have been able to do all the indicators for creative attitude.

In the critical attitude evaluation, all groups received a score of 100 with a very good category. Meaning that all groups were able to think critically to determine which waste is dangerous and would be dealt with and resolved (between liquid waste and solid waste). Besides, they were also able to find one formulation of the problem related to the context of tofu liquid waste management. Finally, they can compare some of the predicted problem solutions that can be used for tofu liquid waste treatment and determine a fluid tofu waste management solution that is suitable for problem-solving.

In the evaluation of cooperation attitude, all groups received a score of 100 with a very good category. Meaning that all groups were able to work together to be actively involved in designing a trial for tofu wastewater treatment. In addition, they can also look for ways to overcome differences of opinion in designing a trial for tofu wastewater treatment and were actively engaged in conducting experiments in handling tofu liquid waste. Finally, they were able to conduct experimental tasks in handling tofu liquid waste following the agreements made.

In the evaluation of tolerance, all groups received a score of 100 with a very good category. Meaning that all groups were able to tolerate each other among fellow students in the group or with other groups. Students can listen to group peers' opinions without interrupting when giving ideas about the design of the experiment. They can accept the views of groupmates, value inappropriate opinions from group friends, and take criticism of their ideas when designing experiments on liquid waste treatment tofu.

In the communicative attitude evaluation, groups 1,4 , and 6 scored 75 with a good category, while groups 2,3 , and 5 scored 100 with the very good category. This means that groups 1, 4, and 6 have been able to present verbally. They were also able to present the results of the tofu wastewater treatment experiment verbally as well as providing opinions and suggestions to other groups regarding the results of the tofu liquid waste treatment experiment. In addition, they can verbally submit the evaluation results of problem solutions related to the context of tofu liquid waste handling. The group has not been able to be active in the question and answer activities, both in presenting the results of the experiment and in evaluating problem solutions related to the context of tofu liquid waste management. As for groups 2, 3, and 5, they have been able to do well in all indicators for communicative attitudes.

The average score of students' attitudes in the implementation of learning is 94.2 , with a very good category. Thus, students' learning outcomes on aspects of view can be classified in the very good category. Then, the score of students' learning outcomes in aspects of skills is 92.7 while students' learning outcomes in aspects of expertise included in the category are very good. 


\section{Students' Learning Outcomes on Psychomotor Aspects}

The psychomotor aspect to be evaluated is the students' skill when conducting experiments and presenting the results of operations. The evaluation of skills is carried out by the teacher to the student group by using the instrument observation sheet. The following Table 13 shows the results of the skills evaluation for each group of students.

Table 13: Results of the Skills Evaluation

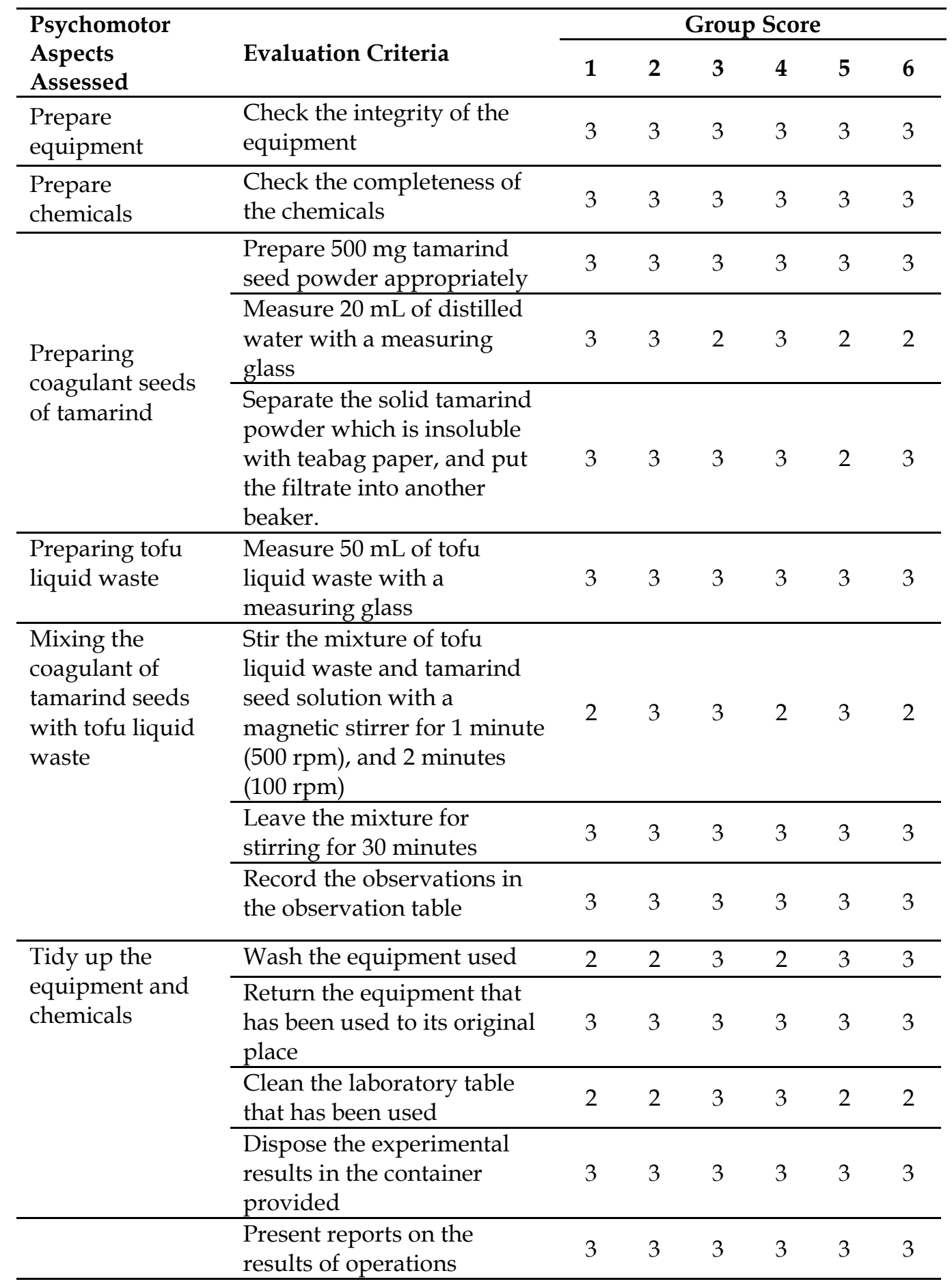




\begin{tabular}{|c|c|c|c|c|c|c|c|}
\hline \multirow{2}{*}{$\begin{array}{l}\text { Psychomotor } \\
\text { Aspects } \\
\text { Assessed }\end{array}$} & \multirow[b]{2}{*}{ Evaluation Criteria } & \multicolumn{6}{|c|}{ Group Score } \\
\hline & & 1 & 2 & 3 & 4 & 5 & 6 \\
\hline \multirow{4}{*}{$\begin{array}{l}\text { Present a report } \\
\text { on the results of } \\
\text { an experiment }\end{array}$} & $\begin{array}{l}\text { following predetermined } \\
\text { formats }\end{array}$ & & & & & & \\
\hline & $\begin{array}{l}\text { Actively involved in-class } \\
\text { discussion }\end{array}$ & 2 & 2 & 2 & 2 & 2 & 1 \\
\hline & $\begin{array}{l}\text { Present, answer and ask } \\
\text { questions politely }\end{array}$ & 3 & 3 & 3 & 3 & 3 & 3 \\
\hline & Total score & 44 & 45 & 46 & 45 & 44 & 43 \\
\hline Score (Scale 100) & & 91.7 & 93.8 & 95.8 & 93.8 & 91.7 & 89.6 \\
\hline Average & & \multicolumn{6}{|c|}{92.7} \\
\hline Category & & VG & VG & VG & VG & VG & VG \\
\hline
\end{tabular}

Based on Table 13, group 1 scored 91.7 with a very good grade, meaning that group 1 has fulfilled the indicators of skills aspects very well. Even so, group 1 did not do the stirring as they should, not optimal when washing tools and cleaning the laboratory table. Group 1 presented the results of the experiment following the format, quite actively involved in the discussion, and polite when giving the results of the analysis.

Group 2 scored 93.8 with a very good category, meaning group 2 has fulfilled the skill aspect indicators very well. Even so, group 2 was not optimal when washing tools and cleaning laboratory tables. Then, group 2 presented the results of the experiment following the format, quite actively involved in the discussion, and polite when giving the results of the analysis.

Group 3 scored 95.8 with a very good category, meaning group 3 has fulfilled the skill aspect indicators very well. Even so, group 3 did not measure aqua distillation using a measuring cup carefully. Then, group 3 presented the results of the experiment according to the format, quite actively involved in the discussion, and polite when giving the results of the analysis.

Group 4 scored 93.8 with a very good category, meaning group 4 has met the skill aspect indicator very well. Even so, group 4 did not do the stirring as they should and was not optimal when washing the appliance. Then, group 4 presented the results of the experiment according to the format, quite actively involved in the discussion, and polite when giving the results of the analysis.

Group 5 scored 91.7 with a very good category, meaning that group 5 has fulfilled the skill aspect indicators very well. Even so, group 5 did not take measurements of the aqua distillation using a measuring cup carefully, did not separate the solids of tamarind seed powder, which did not dissolve with teabag paper correctly and was not optimal when cleaning the laboratory table. Then, group 5 presented the results of the experiment following the format, quite actively involved in the discussion and polite when giving the results of the analysis. 
Group 6 scored 89.6 with a very good category, meaning that group 6 has fulfilled the skill aspect indicators very well. Even so, group 6 did not take measurements of the aqua distillation using a measuring cup carefully, did not do the stirring as they should, and was not optimal when cleaning the laboratory table. Then, group 6 presented the results of the experiment according to the format, and was polite when giving the results of the test, but was less active in the discussion activities.

The average score of students in the element of skills is 92.7 which means that students' learning outcomes on the aspect of skills when conducting experiments and presenting the results of operations on tofu wastewater treatment with Tan type PBL approach belongs to the very good category. Thus, the equipment of chemical analysis is becoming more modern, so the involvement of technology in learning chemistry must be a concern to be integrated so that instructional becomes engaging (JrCrews, 2017).

\section{Conclusion}

This research developed problem-based learning by taking the context of tofu wastewater treatment. This mixed methods research explored how the quality of the planning of problem-based learning, students' performance in implementing steps of problem-based learning, and the effect of problembased learning on cognitive, affective, and psychomotor learning outcomes. The results of this study and their discussion show that problem-based learning in the context of tofu wastewater treatment can improve the quality of processes and students' learning outcomes in chemistry subjects. This research proved that the learning outcomes of students' cognitive, affective, and psychomotor aspects can be improved through problem-solving activities that are close to students' daily lives. In this study, problem-based learning in the context of tofu wastewater treatment applied the concept of chemistry essence about colloids. In contrast to chemistry instruction in general, problem-based learning requires students to simultaneously master the basic concepts of colloids and at the same time apply them in solving the problem of handling tofu liquid waste. In planning this problem-based learning, teachers and students trace information on handling tofu wastewater that is feasible in the industry. To obtain the feasibility of work procedures on an instruction scale, the teacher performs an optimization test in the laboratory. By conducting optimization tests in the laboratory, there are still difficulties for most teachers in schools, given the lack of cultural attitude and scientific culture as well as the limited availability of chemistry laboratory facilities in schools. From the time allocation used, this problem-based learning in handling tofu wastewater requires 4 meetings ( $2 \times 45$ minutes each). The amount of time allocation is quite a lot to study the overall colloidal material in which the curriculum is only 6 meetings. Thus, problem-based learning by taking the context of tofu wastewater treatment will be difficult to be implemented by teachers in general. This happens because the teacher will find it difficult to manage the time for students to learn all the colloidal material. Therefore, further research is needed so that problem-based learning by taking the context of tofu 
wastewater treatment can be carried out in a shorter time allocation while still providing the same quality of learning processes and outcomes.

\section{References}

Aidoo, B., Boanteng, S. K., Kissi, P. S., \& Ofori, I. (2016). Effect of Problem-Based Learning on Students' Achievement in Chemistry. Journal of Education and Practice, 7(33), 103-108.

Anderson, L. W., \& Krathwohl, D. R. (2001). Taxonomy for learning, teaching, and assessing. A Revision of Bloom's Taxonomy of Educational Objectives. New York: Longman.

Aqib, Z. (2009). Penelitian Tindakan Kelas [Classroom Action Research]. Bandung: CV. Yrama Widya.

Arends, R. I. (2012). Learning to Teach 10 th edition. New York: The McGraw-Hill Companies. Retrieved from https://hasanahummi.files.wordpress.com/2017/04/connect-learn-succeedrichard-arends-learning-to-teach-mcgraw-hill-2012.pdf

Ary, D., Jacob, L. C., \& Sorensen, C. (2010). Introduction to Research in Education $8^{\text {th }}$ Edition. California: Wadsworth.

Creswell, J. W. (2009). Research Design: Qualitative, Quantitative, and. Mixed Methods Approaches (Third Edition). Los Angeles: Sage Publications.

Depdikbud. (2016). Permendikbud No. 20, 21, 22, 23, 24 Tahun 2016 tentang Standar Kompetensi Lulusan, Standar Isi, Standar Proses, Standar Penilaian, Kompetensi Inti dan Kompetensi Dasar Pendidikan Dasar dan Menengah [Minister of Education and Culture Regulation Number 20, 21, 22, 23, 24 of 2016 concerning Graduate Competency Standards, Content Standards, Process Standards, Assessment Standards, Core Competencies and Basic Competencies in Primary and Secondary Education]. Jakarta: Depdikbud.

Depdiknas. (2003). Undang-undang Republik Indonesia Number 20 Tahun 2003 Tentang Sistem Pendidikan Nasional [Law of the Republic of Indonesia Number 20 of 2003 concerning the National Education System]. Jakarta: Pemerintah Republik Indonesia.

Ditjenpendas. (2015). Panduan Penilaian untuk Sekolah Menengah Atas [Assessment Guide for High Schools]. Jakarta: Kementrian Pendidikan dan Kebudayaan.

Direktorat Pembinaan Sekolah Menengah Atas. (2017). Model-Model Pembelajaran [Learning Models]. Jakarta: Kementrian Pendidikan dan Kebudayaan.

Dj, L., Fitri, R. L., \& Dewata, I. (2015). Analisis Kecenderungan Pemahaman Konsep Siswa Ditinjau dari Gaya Belajar pada Materi Sistem Koloid di SMA Kerinci [Analysis of the Tendency of Students' Understanding Students' Concepts in terms of Learning Styles on Colloidal System Material in Kerinci High School]. Prosiding SEMIRATA 5-7 Mei 2015, (pp. 523-532). Pontianak: Universitas Tanjungpura.

Griffin, P., \& Care, E. (Eds.). (2015). Assessment and Teaching of 21st Century Skills: Methods and Approach. Dordrecht: Springer. https://doi.org/10.1111/bjet.12308

Gurses, A., Dogar, C., \& Geyik, E. (2015). Teaching Of The Concept Of Enthalpy Using Problem Based Learning Approach. Procedia Social and Behavioral Sciences, 197(2015), 2390-2394.

Hidayati, Y. M., Sa'dijah, C., \& Abd Qohar, S. (2019). Combinatorial Thinking to Solve the Problems of Combinatorics in Selection Type. International Journal of 
Learning, Teaching, and Educational Research, 18(2), 65-75. https://doi.org/10.26803/ijlter.18.2.5

Isa, N. J. M., Jusoh, A. J., \& Razali, M. M. S. H. (2015). Problem-Based Learning: Mandatory Personal Qualities of Effective Facilitators. International Journal of Learning, Teaching, and Educational Research, 13(2), 88-96.

JrCrews, T. R. (2017). Active Learning Across Three Dimensions: Integrating Classic Learning Theory with Modern Instructional Technology. International Journal of Learning, Teaching, and Educational Research, 16(1), 72-83.

Lestari, I. (2013). Pengembangan Bahan Ajar Berbasis Kompetensi [Development of Competency Based Teaching Materials]. Padang: Akademia.

Li, H., \& Du, X. (2015). Teachers' Perspective of their Role and Student Autonomy in the PBL Context in China. International Journal of Learning, Teaching, and Educational Research, 10(2), 18-31. https://doi.org/10.26803/ijlter.17.9.2

Li, H., \& Chen, Y. (2018). Conceptions on PBL Facilitator's Role: A Perspective of Chinese Teacher. International Journal of Learning, Teaching, and Educational Research, 17(9), 18-33. https:// doi.org/10.26803/ijlter.17.9.2

Lin, J. S., Taiwan, Y., \& Liang, C. (2014). The Perceived Influence of Learning Environment on Design Student Imagination. International Journal of Learning, Teaching, and Educational Research, 2(1), 124-136

Machika, P., \& Abrahams, C. (2014). Problem-Based Learning in Construction Engineering within a South African context. International Journal of Learning, Teaching, and Educational Research, 3(1), 69-82.

Meltzer, D. E. (2002). The relationship between mathematics preparation and conceptual learning gains in physics: a possible "hidden variable" in diagnostic pretest scores. American Journal of Physics, 70(12), 1259-1268. https://doi.org/10.1119/1.1514215

Overton, T. L., \& Randles, C. A. (2013). Beyond Problem-based Learning: Using Dynamic PBL in Chemistry. Chemistry Education Research and Practice, 1(3), 1-8. https://doi.org/10.1039/C4RP00248B

Pangaribuan, S. (2016). Pengaruh Pembelajaran Berbasis Masalah terhadap Penguasaan Konsep Siswa SMA pada Konteks Pencemaran Air Sungai akibat Limbah Pemukiman [Effect of Problem Based Learning on High School Students' Concept Mastery in the Context of River Water Pollution due to Residential Waste] (Thesis). Bandung: Departemen Pendidikan Kimia, Universitas Pendidikan Indonesia.

Prastowo, A. (2011). Panduan Kreatif Membuat Bahan Ajar Inovatif [Creative Guide to Making Innovative Teaching Materials]. Yogyakarta: Diva Press.

Pratiwi, Y., Redjeki, T., \& Masykuri, M. (2014). Pelaksanaan Model Pembelajaran Problem based learning (PBL) Pada Materi Redoks Kelas X SMA Negeri 5 Surakarta Tahun Pelajaran 2013/2014 [Implementation of Problem Based Learning (PBL) Learning Model in Class X Redox Material of SMA Negeri 5 Surakarta in 2013/2014 Academic Year]. Jurnal Pendidikan Kimia, 3(3), 40-48.

Pratiwi, E., Nusantara, T., Susiswo, S., Muksar, M., \& Subanji, S. (2019). Characteristics of Students' Cognitive Conflict in Solving a Problem Based on Information Processing Theory. International Journal of Learning, Teaching, and Educational Research, 18(2), 76-88. https://doi.org/10.26803/ijlter.18.2.6

Puspasari, F. (2014). Pemanfaatan Biji Asam Jawa (Tamarindus indica) sebagai Koagulan Alternatif dalam Pengolahan Limbah Cair Industri Tahu [Utilization of Tamarind Seed (Tamarindus indica) as Alternative Coagulant in Tofu Industry Liquid Waste Management] (Thesis). Palembang: Sekolah Pascasarjana, Politeknik Negeri Sriwijaya. 
Ramadhani, G. I., \& Moesria, A. (2013). Pemanfaatan Biji Asam Jawa (Tamarindus indica) Sebagai Koagulan Alternatif dalam Proses Menurunkan Kadar COD dan BOD dengan Studi Kasus pada Limbah Cair Industri Tempe [Utilization of Tamarind Seed (Tamarindus indica) As an Alternative Coagulant in the Process of Reducing COD and BOD Levels by Case Study on Tempe Industry Liquid Waste]. Jurnal Teknik Pomits, 2(1), 22-26.

Sanjaya, W. (2006). Strategi Pembelajaran Berorientasi Standar Proses Pendidikan [Standard Oriented Education Process Learning Process]. Jakarta: Kencana Prenada Media Group.

Sanjaya, W. (2015). Perencanaan dan Desain Sistem Pembelajaran [Learning System Planning and Design]. Jakarta: Kencana.

Savery, J. R. (2006). Overview of Problem-based Learning: Definitions and Distinctions, The Interdisciplinary Journal of Problem-based Learning, 1(1), 9-20. http://dx.doi.org/10.7771/1541-5015.1002

Schell, R., \& Kaufman, D. (2015). Designing PBL Case Studies for Patient-Centered Care. International Journal of Learning, Teaching, and Educational Research, 13(3), 160-180.

Septiana, A., Inayah, N. S., Azizah, N., \& Aditya, R. R. (2014). Pembuatan Tawas Menggunakan Kalium dan Kalium Hidroksida [The Making of Alum Using Potassium and Potassium Hydroxide]. Jakarta: UIN Syarif Hidayatullah.

Stivaktakis, S. (2017). The «Learning in Depth» Proposal: Its Importance as a Science Curriculum Strand. International Journal of Learning, Teaching, and Educational Research, 16(2), 13-22. https:// doi.org/10.26803/ijlter.16.12.2

Sudarmo, U. (2017). Kimia Untuk SMA/MA Kelas XI [Chemistry for Senior High School Class XI]. Surakarta: Erlangga

Tan, O. S. (2003). Problem-Based Learning Innovation: Using Problems to Power Learning in the 21st Century. Singapore: Cengage Learning.

Üce, M., \& Ateş, İ. (2016). Problem-based Learning Method: Secondary Education 10th Grade Chemistry Course Mixtures Topic. Journal of Education and Training Studies, 4(2), 30-35. https://doi.org/10.11114/jets.v4i12.1939

Uno, H. B. (2010). Perencanaan Pembelajaran [Lesson Planning]. Jakarta: Bumi Askara.

Widana, I. W. (2017). Modul Penulisan Soal Hots Untuk Ujian Sekolah [HOTS Question Formulation Module for School Exams]. Jakarta: Direktorat Pembinaan SMA, Direktorat Jenderal Pendidikan Dasar dan Menengah Kementerian Pendidikan dan Kebudayaan.

Wijayanti, A., \& Wulandari T. (2016). Efektivitas Model CTL dan Model PBL terhadap Hasil Belajar IPS [The Effectiveness of the CTL and PBL Model on Social Studies Learning Outcomes]. Harmoni Sosial: Jurnal Pendidikan IPS, 3(2), 112124. https://doi.org/10.21831/hsjpi.v3i2.7908

Wulandari, D. R., Marheni, M., \& Nurbaiti, N. (2014). Analisis Persepsi Siswa pada Materi Koloid dalam Pembelajaran Kimia dengan Menggunakan Mental Image Analysis of Students [Analysis of Student Perception on Collodial Material in Chemistry Learning Using Mental Image Analysis of Students]. JRPK: Jurnal Riset Pendidikan Kimia,4(1), 271-277. https:// doi.org/10.21009/JRPK.041.07

Zulfaidhah, Z., Palenewen, E., \& Hardoko, A. (2018). Needs Analysis in the Problem Based Learning (PBL) Model Tools and Problems Regarding 7th Grade Students' Science Learning Outcome at SMPN 2. Bongan. BIODIK, 4(1), 48-59. https://doi.org/10.22437/bio.v4i1.5508 


\section{APPENDIX}

\section{TEST ITEMS}

1. The tofu making process may produce solid waste and liquid waste which have a negative impact on the environment. Solid waste can pollute the soil, where the soil gets dirty and creates an unpleasant odor. While tofu liquid waste is usually discharged directly into the river so that it pollutes the river, such as increasing water turbidity, increasing contamination of viruses and bacteria, reducing the level of dissolved oxygen in the water, and affecting the water ecosystem.

Based on the above reading, the waste with a higher negative impact on the environment is ....

A. tofu solid waste because it can pollute the soil, increase virus and bacterial contaminants, and cause unpleasant odors

B. tofu solid waste because it can pollute the soil, reduce oxygen levels in the air, and cause unpleasant odors

C. tofu liquid waste because it can reduce water turbidity, reduce oxygen levels in the air, and cause unpleasant odors

D. tofu liquid waste because it can increase turbidity, increase contamination of viruses and bacteria, and reduce levels of dissolved oxygen in the water

E. both tofu wastes have the same level of pollution

2. Consider the following stages of the tofu making process:

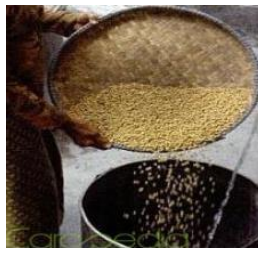

winnowing soybean

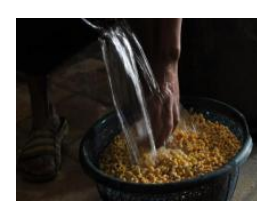

washing soybean

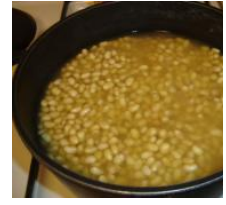

soaking soybean

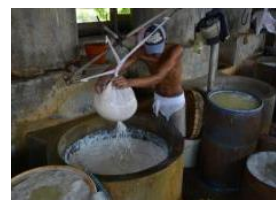

filtering soybean porridge

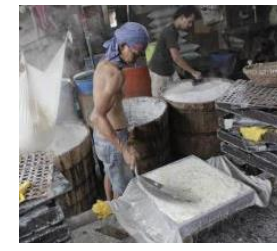

coagulate soybean juice

The tofu making process will produce several types of waste, based on your analysis, waste that has more potential to pollute the environment is ...
A. soybean skin from winnowing soy
B. soybean wash water
C. soaking water from soybean
D. tofu pulp from filtering soybean porridge
E. water from coagulating soybean juice 
3. A student tries to analyze tofu liquid waste. The waste has turbid physical characteristics, turbidity can occur due to the presence of colloidal particles in the tofu liquid waste. This liquid waste is usually directly discharged into water such as rivers without prior handling so that it can pollute the river. The most appropriate formulation of the problem if you want to research tofu liquid waste so as not to pollute the river is ...

A. What will happen to humans if they consume river water that is contaminated with tofu liquid waste?

B. What are the physical characteristics of river water that has been polluted by tofu liquid waste?

C. How do you deal with the turbidity of tofu liquid waste due to the presence of colloidal particles in tofu liquid waste?

D. Why does tofu liquid waste contain colloid particles?

E. How to recognize the characteristics of colloidal particles present in tofu liquid waste and other wastes?

4. Tofu liquid waste contains colloidal particles which can cause turbidity so it must be handled first before being discharged into water. The way to handle tofu liquid waste through the coagulation process is ....
A. filtering colloidal particles
B. enlarging the size of colloidal particles
C. absorbing charge by the surface of colloidal particles
D. maintaining colloidal stability
E. absorbing static electricity charges by colloidal particles

5. One way to handle tofu liquid waste is to add alum. The purpose of adding alum is to ...
A. eliminate odor in tofu liquid waste
B. make the temperature of tofu liquid waste become room temperature
C. kill bacteria in tofu liquid waste
D. coagulate colloidal particles in tofu liquid waste
E. make tofu liquid waste immediately drinkable

6. In addition to alum, tofu liquid waste management can be done by using natural ingredients, such as tamarind. Tamarind has positively charged metal ions, while tofu liquid waste is a negative colloid. In what ways do tamarind seeds and alum handle the tofu liquid waste?
A. Coagulation with the presence of electrolytes
B. Coagulation by mixing different colloid loads
C. Filtration of negative colloids with positive ions
D. Adsorption of positive charges by colloids
E. Negative colloidal electrophoresis towards the pole of the positive electric charge


7. Following are the steps for handling tofu liquid waste with tamarind:

1) Put $50 \mathrm{~mL}$ of tofu liquid waste into a $100 \mathrm{~mL}$ beaker.

2) Mix the mixture of tofu liquid waste and tamarind seed powder using a magnetic stirrer for 1 minute (500 rpm) or 2 minutes (100 rpm).

3) Put the tamarind seed solution into a beaker containing tofu liquid waste

4) Weigh the $500 \mathrm{mg}$ tamarind seed powder and add $20 \mathrm{~mL}$ of distilled water.

The correct arrangement for handling tofu liquid waste with tamarind is ...
A. $1-2-3-4$
B. $1-3-2-4$
C. $1-3-2-4$
D. $1-4-2-3$
E. 1-4-3-2

8. A student takes a sample of $50 \mathrm{~mL}$ of tofu liquid waste to be handled using tamarind seeds and moringa seeds. So that the following results are obtained:

\begin{tabular}{cccc}
\hline $\begin{array}{c}\text { Tamarind Seed } \\
\text { Content }\end{array}$ & $\begin{array}{c}\text { Decrease in } \\
\text { Turbidity (\%) }\end{array}$ & $\begin{array}{c}\text { Moringa Seed } \\
\text { Content }\end{array}$ & $\begin{array}{c}\text { Decrease in } \\
\text { Turbidity (\%) }\end{array}$ \\
\hline $\begin{array}{c}250 \mathrm{mg} / 50 \\
\mathrm{~mL} \text { tofu liquid } \\
\text { waste }\end{array}$ & 70.59 & $\begin{array}{c}250 \mathrm{mg} / 50 \\
\mathrm{~mL} \text { tofu liquid } \\
\text { waste }\end{array}$ & 64.91 \\
\hline $\begin{array}{c}500 \mathrm{mg} / 50 \\
\mathrm{~mL} \text { tofu liquid } \\
\text { waste }\end{array}$ & 76.47 & $\begin{array}{c}500 \mathrm{mg} / 50 \\
\text { mL tofu liquid } \\
\text { waste }\end{array}$ & 66.67 \\
\hline
\end{tabular}

Based on the table, the most effective coagulants and their content are ...
A. $250 \mathrm{mg}$ of tamarind seeds / $50 \mathrm{~mL}$ of tofu liquid waste
B. $500 \mathrm{mg}$ tamarind seeds / $50 \mathrm{~mL}$ tofu liquid waste
C. $250 \mathrm{mg}$ moringa seeds / $50 \mathrm{~mL}$ tofu liquid waste
D. $500 \mathrm{mg}$ moringa seeds / $50 \mathrm{~mL}$ tofu liquid waste
E. tamarind seeds are not more effective than moringa seeds 